\title{
miR-155, miR-191, and miR-494 as diagnostic biomarkers for oral squamous cell carcinoma and the effects of Avastin on these biomarkers
}

\author{
Naghmeh Emami ${ }^{1}$, Abdolreza Mohamadnia ${ }^{2,3, \star}$, Masoumeh Mirzaei ${ }^{1}$, Mohammad Bayat ${ }^{4,5}$, \\ Farnoush Mohammadi ${ }^{4,5}$, Naghmeh Bahrami ${ }^{4,6, *}$ \\ ${ }^{I}$ Department of Biology, Faculty of Basic Sciences, Islamic Azad University, North Tehran Branch, ${ }^{2}$ Chronic Respiratory Diseases \\ Research Center, National Research Institute of Tuberculosis and Lung Diseases (NRITLD), Shahid Beheshti University of Medical \\ Sciences, ${ }^{3}$ Department of Biotechnology, School of Advanced Technologies in Medicine, Shahid Beheshti University of Medical Sciences, \\ ${ }^{4}$ Craniomaxillofacial Research Center, Tehran University of Medical Sciences, ${ }^{5}$ Department of Oral and Maxillofacial Surgery, School \\ of Dentistry, Tehran University of Medical Sciences, ${ }^{6}$ Department of Tissue Engineering and Applied Cell Sciences, School of Advanced \\ Technologies in Medicine, Tehran University of Medical Sciences, Tehran, Iran
}

\begin{abstract}
J Korean Assoc Oral Maxillofac Surg 2020;46:341-347)
Objectives: Oral squamous cell carcinoma (OSCC) is one of the most common types of head and neck cancer. MicroRNAs, as new biomarkers, are recommended for diagnosis and treatment of different types of cancers. Bevacizumab, sold under the trade name Avastin, is a humanized whole monoclonal antibody that targets and blocks VEGF-A (vascular endothelial growth factor A; angiogenesis) and oncogenic signaling pathways.

Materials and Methods: This study comprised 50 cases suffering from OSCC and 50 healthy participants. Peripheral blood samples were collected in glass test tubes, and RNA extraction was started immediately. Expression levels of miR-155, miR-191, and miR-494 biomarkers in the peripheral blood of OSCC-affected individuals and healthy volunteers in vivo were evaluated using real-time PCR. The influence of Avastin on the expression levels of the aforementioned biomarkers in vitro and in the HN5 cell line was also investigated.

Results: Expression levels of miR-155, miR-191, and miR-494 in the peripheral blood of individuals affected by OSCC were higher than in those who were healthy. Moreover, Avastin at a concentration of $400 \mu \mathrm{M}$ caused a decrease in the expression levels of the three biomarkers and a 1.5-fold, 3.5-fold, and 4-fold increase in apoptosis in the test samples compared to the controls in the HN5 cell line after 24, 48, and 72 hours, respectively.

Conclusion: The findings of this study demonstrate that overexpression of miR-155, miR-191, and miR-494 is associated with OSCC, and Avastin is able to regulate and downregulate the expression of those biomarkers and increase apoptosis in cancerous cells in the HN5 cell line
\end{abstract}

Key words: Oral cancer, MicroRNA, Avastin, Real-time polymerase chain reaction, Apoptosis

[paper submitted 2020. 3. 6 / revised 2020. 5. 1 / accepted 2020. 5. 5]

\author{
Naghmeh Bahrami \\ Department of Tissue Engineering and Applied Cell Sciences, School \\ of Advanced Technologies in Medicine, Tehran University of Medical \\ Sciences, Tehran 1411713135, Iran \\ TEL: +98-2188029395 FAX: +98-2188633039 \\ E-mail:n-bahrami@sina.tums.ac.ir \\ ORCID: https://orcid.org/0000-0002-3575-4094
}

\footnotetext{
Abdolreza Mohamadnia

Chronic Respiratory Diseases Research Center, National Research Institute of Tuberculosis and Lung Diseases (NRITLD), Shahid Beheshti University of Medical Sciences, Tehran 1955841452, Iran

TEL: +98-2127122567 FAX: +98-2120105050

E-mail:mohamadnia.ar@gmail.com

ORCID: https://orcid.org/0000-0001-9662-7462

*These authors contributed equally to this work as co-corresponding authors.

(a) This is an open-access article distributed under the terms of the Creative Commons Attribution Non-Commercial License (http://creativecommons.org/ licenses/by-nc/4.0/), which permits unrestricted non-commercial use, distribution, and reproduction in any medium, provided the original work is properly cited. Copyright (C) 2020 The Korean Association of Oral and Maxillofacial Surgeons. All rights reserved.
}

\section{Introduction}

Oral squamous cell carcinoma (OSCC) is the sixth most common cancer worldwide ${ }^{1}$. Only $50 \%$ of patients survive up to five years because they are diagnosed in advanced stages ${ }^{2}$. Given the severity and complication of the disease, using a diagnostic tool is necessary for clinical prognosis ${ }^{1}$. This goal can be achieved by identification of molecular pathways and biomarkers to prognosticate and detect OSCC at early stages.

MicroRNAs (miRNAs) are small endogenous non-coding RNAs of 20-24 nucleotides in length. As regulators, they play an essential role in biological processes, such as embryonic development (embryogenesis), cell proliferation, cellular differentiation, cell migration, and apoptosis ${ }^{3}$. Therefore, any change in miRNA expression level may have a link to vari- 
ous diseases like cancer. A number of miRNAs function as both tumor suppressors and as oncogenes (oncomiR) ${ }^{4,5}$, having been shown to be involved in various cancers including breast cancer $^{6-8}$, gastric cancer ${ }^{9-11}$, and OSCC ${ }^{12-14}$. Contradictory results have been reported about the miRNA expression profiles of OSCC in human societies, and extensive research needs to be conducted before clinical use $\mathrm{e}^{15,16}$. MiR-191 is one of the highly expressed and stable miRNAs found in human serum and saliva and is a potential non-invasive biomarker in humans ${ }^{17}$. MiR-191 is overexpressed in some cancers such as gastric cancer and has been shown to promote cell growth and suppress apoptosis ${ }^{18}$. MiR-155 plays a prominent role in cancer biology and can be both a suppressor and an oncogene ${ }^{19}$. As an oncomiR, miR-155 has been recognized as a carcinogen in OSCC $^{20}$. MiR-494 is also identified as an oncomiR and is a key player in advancement of the cell cycle and proliferation. MiR-494 overexpression decreases PTEN and P27 expression ${ }^{21}$.

Bevacizumab, sold under the trade name Avastin and approved by the U.S. Food and Drug Administration, is a fully humanized whole monoclonal antibody ${ }^{22}$ that is used to cure a number of types of cancers, including colorectal cancer, lung cancer ${ }^{23}$, ovarian cancer, and glioblastoma ${ }^{24}$. Bevacizumab can act as an angiogenesis inhibitor, cause regulation of miRNA expression, induce cell apoptosis, and prevent OSCC progression ${ }^{25}$.

This study aims to investigate the change in expression levels of miR-155, miR-191, and miR-494, as diagnostic biomarkers, in the serum of OSCC patients compared to that of healthy participants. To explore the effects of Avastin on apoptosis, the expression levels of miR-155, miR-191, and miR-494, as treatment and diagnostic biomarkers, were reviewed in the HN5 cell line to avoid the unnecessary and exorbitant cost of medical treatments for unresponsive patients.

\section{Materials and Methods}

\section{Selection of patients and sampling}

This case-control study consists of 50 patients who were referred to Tehran University of Medical Sciences, Tehran, Iran, from March 2019 to January 2020. Cases were selected based on physical examination prior to any treatment and were suspected to have OSCC. Another 50 healthy participants were included in this study as the control group after being examined by a doctor and signing the letter of consent (ethical code: IR.TUMS.VCR.REC.1397.792). These people were chosen from the same age groups. Peripheral blood (2 $\mathrm{mL}$ ) was collected from the 50 OSCC and 50 healthy subjects, and RNA was immediately extracted.

\section{Blood RNA extraction and quantitative real-time polymerase chain reaction}

The extraction of total RNA and small RNAs was carried out using RNeasy Mini Kit (Qiagen, Hilden, Germany), according to kit instructions. The quality of the extracted RNA was evaluated by NanoDrop, and the ratio of absorbance at $260 \mathrm{~nm}$ and $280 \mathrm{~nm}$ was used to assess the RNA concentration. cDNA was produced using a kit from Zistroyesh (Tehran, Iran), real-time reverse transcription polymerase chain reaction (RT-PCR) was performed with the same kit and with a Rotor-Gene (Qiagen, Hilden, Germany). To normalize miRNA expression, we used U6 as a calibrator (housekeeping gene). Temperatures and reaction times were adjusted according to kit instructions.(Table 1) The results were interpreted after each reaction and based on amplification and melting peak curves. Average blood miRNA expression level was calculated using the $\Delta \Delta \mathrm{Ct}$ method and compared to that of U6 SnRNA.

The $2^{-\Delta \Delta \mathrm{CT}}$ method was used to determine the fold change of target miRNA compared to the expressed miRNA in the control group.

\section{Cell culture}

The HN5 cell line, under the cellular code C196, was obtained from Pasteur Institute of Iran (Tehran) and transferred to a laboratory at the University of Tehran to be cultured. HN5 cells were incubated and grew in a humidified incubator at $5 \% \mathrm{CO}_{2}$ and $37^{\circ} \mathrm{C}$. The growth medium, RPMI-1640 (Gibco, Carlsbad, CA, USA), was enriched with phosphatebuffered saline (PBS), $100 \mathrm{U} / \mathrm{mL}$ of penicillin, $100 \mu \mathrm{g} / \mathrm{mL}$ of streptomycin, and 10\% fetal bovine serum (FBS).

Table 1. Temperature conditions of real-time polymerase chain reaction

\begin{tabular}{clc}
\hline Cycle & Duration of cycles & Temperature $\left({ }^{\circ} \mathrm{C}\right)$ \\
\hline 1 & $15 \mathrm{~min}$ & 95 \\
$35-40$ & $15-30 \mathrm{~s}$ & 95 \\
& $60 \mathrm{~s}$ & $55-60$ \\
1 & Melting analysis & $55-95$ \\
\hline
\end{tabular}

Naghmeh Emami et al: miR-155, miR-191, and miR-494 as diagnostic biomarkers for oral squamous cell carcinoma and the effects of Avastin on these biomarkers. J Korean Assoc Oral Maxillofac Surg 2020 


\section{MTT cell proliferation assay}

Cell proliferation was assessed using MTT assay. HN5 cells in the exponential phase were placed in 96-well plates. They continued to grow at a concentration of $5 \times 10^{3}$ cells per well in the RPMI-1640 medium supplemented with 10\% PBS. Different concentrations of Avastin $(0-650 \mu \mathrm{M})$ dissolved in $1 \%$ DMSO were added to the HN5 cells and incubated in 5\% $\mathrm{CO}_{2}$ at $37^{\circ} \mathrm{C}$ for 24,48 , and 72 hours. The HN5 cells were then washed with PBS. Next, $200 \mu \mathrm{L}$ of the culture medium containing $0.5 \mathrm{mg} / \mathrm{mL}$ of MTT was added to the cells, which were incubated in $5 \% \mathrm{CO}_{2}$ at $37^{\circ} \mathrm{C}$ for four hours. The cells were lysed after the aforementioned time periods, and purple formazan crystals were measured at $570 \mathrm{~nm}$ and $630 \mathrm{~nm}$ wavelengths using an ELISA reader. The percentage of cell viability was calculated.

\section{Annexin-PI flow cytometry}

Apoptosis of cells was analyzed using the annexin V/propidium iodide (PI) test. In detail, $1 \mathrm{~mL}$ of the cell suspension (equal to $5 \times 10^{5}$ cells in $\mathrm{ml}$ ) was poured into six-well plates, and then $2 \mathrm{~mL}$ of the growth medium plus 10\% FBS were added to the cells. Subsequently, Vanadium Schiff base complex was added to the cells. After the incubation of cells, sixwell plates were washed with PBS and centrifuged at room temperature for six minutes. The liquid at the top of the sample was discarded, and $10 \mu \mathrm{L}$ of annexin was added and incubated on ice in the dark. After 30 minutes, $1 \mathrm{~mL}$ of PBS was added to the samples, which were then evaluated by flow cytometry.

\section{Cell culture RNA extraction and quantitative real-time RT-PCR}

Total RNA was extracted using the RNeasy Mini Kit, according to kit instructions. The concentration of extracted RNA was assessed by a NanoDrop, and cDNA was produced

Table 2. Mean age comparison of oral squamous cell carcinomaaffected and healthy participants by t-test

\begin{tabular}{lcc}
\hline \multicolumn{1}{c}{ Main group } & Age $(\mathrm{yr})$ & $P$-value \\
\hline Patients $(\mathrm{n}=50)$ & $44.12 \pm 8.44(26-68)$ & 0.442 \\
Healthy participants $(\mathrm{n}=50)$ & $45.54 \pm 9.10(25-68)$ & \\
\hline
\end{tabular}

Values are presented as mean \pm standard deviation (range).

Naghmeh Emami et al: miR-155, miR-191, and miR-494 as diagnostic biomarkers for oral squamous cell carcinoma and the effects of Avastin on these biomarkers. $J$ Korean Assoc Oral Maxillofac Surg 2020 using the Zistroyesh Kit. Real-time RT-PCR was performed according to the protocols mentioned in the previous stage.

\section{Statistical analysis}

The sample size was calculated considering marker positivity in both groups, and type I and type II errors were perceived to be $5 \%$ and $20 \%$, respectively. Results were analyzed by IBM SPSS Statistics (ver. 20; IBM, Armonk, NY, USA), and the mean and standard deviation were measured. To analyze the differences between the sample and control groups or the link between miRNA expression levels and clinical and pathological features, paired sample t-test was applied. $P$-values less than 0.05 were statistically significant.

\section{Results}

In this research, the statistical population consisted of 50 OSCC patients and 50 healthy participants. These two groups were age-matched. Groups were compared according to age using the t-test, and no significant difference was found; therefore, it was concluded that age would not be an issue in this study.(Table 2) The patient group consisted of 26 males (52.0\%) and 24 females (48.0\%) individuals, while the healthy group included 28 males (56.0\%) and 22 females $(44.0 \%)$ individuals.

All the real-time RT-PCR reactions were performed with duplicate repetitions. Two vials of cDNA from each sample were made and tested. The results were interpreted according

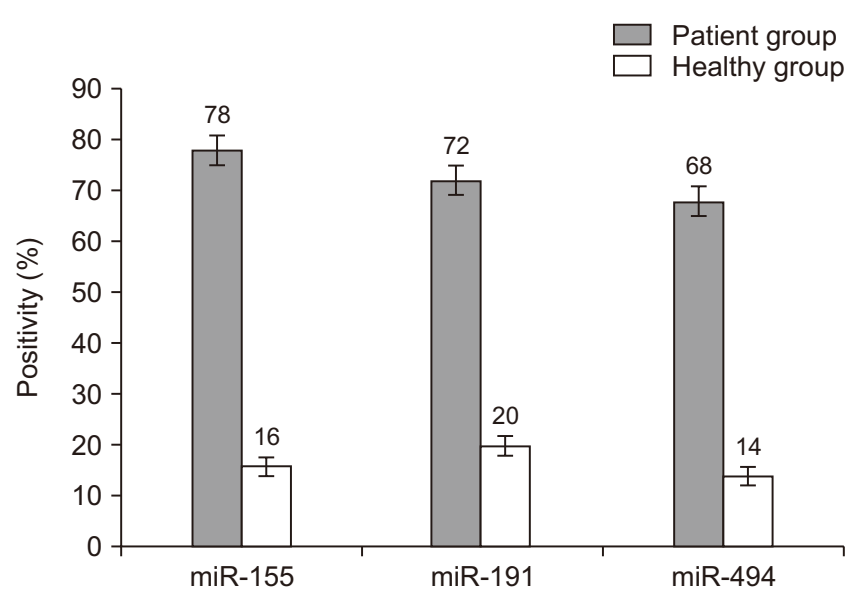

Fig. 1. The percentage positivity for miR-155, miR-191, and miR494 biomarkers in the peripheral blood of cancer patients and healthy individuals.

Naghmeh Emami et al: miR-155, miR-191, and miR-494 as diagnostic biomarkers for oral squamous cell carcinoma and the effects of Avastin on these biomarkers. J Korean Assoc Oral Maxillofac Surg 2020 
to the melting curve.

The miR-155, miR-191, and miR-494 biomarkers were positive in $39(78.0 \%), 36(72.0 \%)$, and $34(68.0 \%)$ of 50 OSCC-affected participants, respectively, and their numbers in healthy individuals were $8(16.0 \%), 10(20.0 \%)$, and 7 (14.0\%).(Fig. 1) The statistical comparison of these biomarkers in the sick and healthy groups was conducted by twosample binomial, which indicated a statistically significant difference between these two groups $(P<0.001)$.

\section{Calculating the differences between expression of biomarkers in the two groups}

First, cycle threshold $(\mathrm{Ct})$ of each sample (as mentioned before) was determined. The comparative differences between the test and control samples were calculated using the $2^{-\Delta \Delta \mathrm{Ct}}$ formula. In peripheral blood, the expression of miR191, miR-494, and miR-155 biomarkers was on average 2.4, 1.5 , and 1.08 times higher, respectively, in sick cases than in healthy individuals.(Fig. 2)

\section{Cell Viability}

The comparison of cell viability at $0 \mu \mathrm{M}$ concentration of Avastin at three times showed significant differences $(P<0.001)$. The longer was the elapsed time, the greater was the cell growth. The survival of HN5 cells in the $100 \mu \mathrm{M}$ concentration of Avastin also differed significantly with time $(P=0.02)$, although that at the $200 \mu \mathrm{M}$ concentration of Avas-

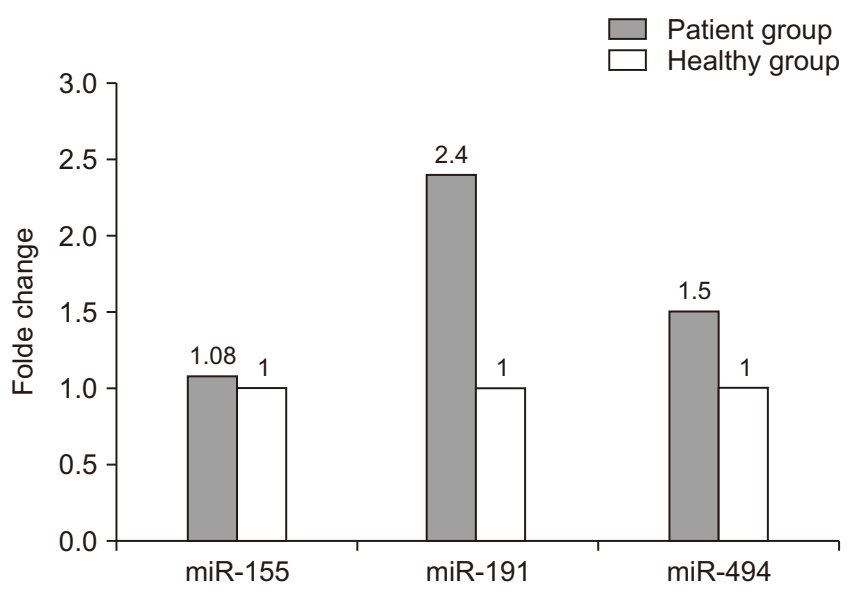

Fig. 2. The difference of expression of miR-155, miR-191, and miR-494 biomarkers between the test and control samples.

Naghmeh Emami et al: miR-155, miR-191, and miR-494 as diagnostic biomarkers for oral squamous cell carcinoma and the effects of Avastin on these biomarkers. $J$ Korean Assoc Oral Maxillofac Surg 2020 tin showed no significant difference $(P=0.35)$. The survival of HN5 cells in the $400 \mu \mathrm{M}$ concentration of Avastin after 48 hours significantly decreased compared to that in the first 24 hours $(P=0.001)$, and a significant reduction was observed in the $600 \mu \mathrm{M}$ concentration of Avastin after 72 hours compared to the first 24 and 48 hours ( $P=0.005$ and 0.05 , respectively).

\section{Apoptotic cell analysis using flow cytometry}

After incubation of the HN5 cell line in the 0, 100, 200, 400 , and $600 \mu \mathrm{M}$ concentrations of Avastin, apoptosis of HN5 cells was analyzed using flow cytometry with annexin $\mathrm{V}$ and PI after 24, 48, and 72 hours. In the $400 \mu \mathrm{M}$ concentration, the average percentage of apoptotic cells in the control samples was $10 \%$ at each time marker, while that in the test samples was $14.8 \%, 33.4 \%$, and $38.8 \%$ at the $24-$, 48-, and 72-hour time markers, respectively, which indicated a 1.5-fold, 3.5-fold, and 4-fold increase in apoptosis in the test samples compared to the controls.

\section{Analysis of expression of miR-155, miR-191, and miR- 494 biomarkers in HN5 cells}

The expression of miR-155, miR-191, and miR-494 in HN5 cells were analyzed using real-time PCR after 48 hours incubation with different concentrations (0, 100, 200, 400, and $600 \mu \mathrm{M})$ of Avastin. The result indicated the reducing effect of Avastin on the relevant miRNA expression and the positive effect of the medicine on treatment.(Table 3 )

\section{Discussion}

There are a number of studies on the role of miRNA and miRNA dysregulation in different diseases, including cancers. MiRNAs are endogenously expressed small non-coding RNAs that play a major role in almost all biological cellular

Table 3. Real-time polymerase chain reaction results of fold change for miR-155, miR-191, and miR-494

\begin{tabular}{cccc}
\hline \multirow{2}{*}{$\begin{array}{c}\text { Concentration } \\
(\mu \mathrm{M})\end{array}$} & \multicolumn{3}{c}{ Fold change } \\
\cline { 2 - 4 } & miR-155 & miR-191 & miR-494 \\
\hline 0 & 1.02 & 2.2 & 1.6 \\
100 & 0.72 & 1.8 & 1.1 \\
200 & 0.6 & 1.2 & 0.9 \\
400 & 0.44 & 0.8 & 0.5 \\
600 & 0.24 & 0.4 & 0.3 \\
\hline
\end{tabular}

Naghmeh Emami et al: miR-155, miR-191, and miR-494 as diagnostic biomarkers for oral squamous cell carcinoma and the effects of Avastin on these biomarkers. J Korean Assoc Oral Maxillofac Surg 2020 
pathways. Thus, they affect many cancer-related cellular processes, such as proliferation, cell cycle control, apoptosis, differentiation, cell migration, and cell metabolism ${ }^{26,27}$. Many studies have reported that miRNAs can operate as oncogenes or tumor suppressor genes ${ }^{27,28}$.

Various strategies exist for diagnosing OSCC in later stages and after metastasis, such as sputum cytology and endoscopy. Therefore, there is a compelling reason to find a proper and non-invasive method such as use of tumor biomarkers to enable diagnosis in earlier stages ${ }^{29}$. The unnatural expression patterns of miRNAs probably have valuable information as important biomarkers for diagnosis, treatment, and progno$\operatorname{sis}^{30}$.

In this study, we showed that the expression of miR-155, miR-191, and miR-494 in the peripheral blood of those with OSCC increased 1.08-fold, 2.4-fold, and 1.5-fold, respectively, so they can be considered as biomarkers with high diagnosis potential in early stages. Furthermore, after 24, 48, and 72 hours of incubation of $\mathrm{HN} 5$ cells with Avastin concentrations of $0,100,200,400$, and $600 \mu \mathrm{M}$, in the $400 \mu \mathrm{M}$ concentration, the percentage of apoptotic cells in the control samples was $10 \%$ on average and that in test samples was $14.8 \%$, $33.4 \%,(P=0.003)$, and $38.8 \%(P=0.02)$ after 24,48 , and 72 hours, respectively. This finding shows a 1.5-fold, 3.5-fold, and 4-fold increase in apoptosis in the test samples compared to the controls. Meanwhile, following real-time PCR in HN5 cells after 48 hours incubation with Avastin at concentrations of $100,200,400$, and $600 \mu \mathrm{M}$, the levels of overexpressed miR-155, miR-191, and miR-494 decreased, indicating a positive effect of the medicine on treatment. These results suggest that the three miRNAs mentioned could be good markers for diagnosis and follow-up of treatment.

Evidence has revealed changes in expression of miR-155 in carcinogenesis. Overexpression of miR-155 has also been demonstrated in breast cancer ${ }^{6}$, non-small cell lung cancer $(\mathrm{NSCLC})^{31}$, gastric cancer ${ }^{9}$, and osteosarcoma ${ }^{32}$, which is in agreement with our results. However, in the Zare et al. ${ }^{33}$ study on gastric cancer, statistically significant downregulation of miR-155-5p ( $P=0.0018)$ was reported, which is contradictory to the result obtained here.

MiR-191 dysregulation in different cancers, such as in hepatocellular carcinoma ${ }^{34}$, breast cancer ${ }^{7}$, pancreatic cancer ${ }^{35}$, gastric cancer ${ }^{10}$, different human cell lines of colorectal can$\operatorname{cer}^{36}$, and $\mathrm{OSCC}^{13}$, has increasingly been detected, which is in agreement with the overexpression of miR-191 in OSCC cases in this study. However, downregulation of miR-191 in follicular adenoma, anaplastic thyroid carcinoma, and papil- lary thyroid carcinoma ${ }^{37}$ and downregulation of miR-191-5p in the renal cell carcinoma cell lines $\mathrm{ACHN}$ and $786-\mathrm{O}^{38}$ were in conflict with the results of this study.

MiR-494 expression in breast cancer cell lines MDAMB-468 and MDA-MB-231 ${ }^{39}$, NSCLC cancer tissues and cell line ${ }^{8}$, hepatocellular carcinoma ${ }^{40}$, and colorectal cancer ${ }^{41}$ increases, which corresponds with our result regarding miR494 overexpression in OSCC. However, some studies have indicated a connection between miR-494 downregulation and cervical tumors, ovarian tumors ${ }^{42,43}$, and gastric cancer ${ }^{11}$, which contradicts our findings.

This study lends support to the results obtained by Zhao et al. ${ }^{44}$ concerning the anti-tumor effects of Avastin/bevacizumab on the human colorectal cancer HT-29 cell line. In this research, the anti-tumor effects of Avastin was in line with the results achieved in the field of effective and improving effects in treatment of patients affected by different types of tumors such as metastatic renal cell cancer, NSCLC, pancreatic cancer, breast cancer ${ }^{24}$. Induction of apoptosis and prevention of tumor growth and liver metastasis in advanced gastric cancer are also among the antitumor effects of Avastin ${ }^{45}$.

In the present investigation, our findings reflect the changes in expression patterns of miR-155, miR-191, and miR-494 in OSCC. Avastin/bevacizumab controls cell proliferation, induces apoptosis, and decreases the viability of cells in the HN5 cancer cell line while also decreasing the expression levels of miR-155, miR-191, and miR-494. Therefore, it seems that the expression levels of the three mRNAs in the blood of those affected by OSCC could serve as diagnostic biomarkers in the early stages of disease.

\section{Conclusion}

In treatment with Avastin in chemotherapy, miR-155, miR191, and miR-494 can be regarded as biomarkers for progression of treatment. Avastin functions as an anti-tumor drug that induces apoptosis in the HN5 cell line and downregulates the expression of the aforementioned biomarkers in OSCC.

\section{ORCID}

Naghmeh Emami, https://orcid.org/0000-0001-9443-5635

Abdolreza Mohamadnia, https://orcid.org/0000-0001-96627462

Masoumeh Mirzaei, https://orcid.org/0000-0003-0702-3961

Mohammad Bayat, https://orcid.org/0000-0002-8658-4750

Farnoush Mohammadi, https://orcid.org/0000-0002-2347- 


\section{9}

Naghmeh Bahrami, https://orcid.org/0000-0002-3575-4094

\section{Authors' Contributions}

A.M. and N.B. conceived the idea, N.B. analyzed the data, and M.B. drafted the article. M.M. and F.M. helped with research procedures. N.E. and A.M. collected the data and performed the research.

\section{Acknowledgements}

This study was funded by Tehran University of Medical Sciences (TUMS) (grant No. 97-03-106-39755). Further thanks to the Islamic Azad University, North Tehran branch.

\section{Ethics Approval and Consent to Participate}

All samples were obtained with patients providing extensively informed consent, and the study was approved by the Tehran University of Medical Sciences ethical committee (ethical code: IR.TUMS.VCR.REC.1397.792).

\section{Conflict of Interest}

No potential conflict of interest relevant to this article was reported.

\section{References}

1. Kumar M, Nanavati R, Modi TG, Dobariya C. Oral cancer: etiology and risk factors: a review. J Cancer Res Ther 2016;12:458-63. https://doi.org/10.4103/0973-1482.186696

2. Ferlay J, Soerjomataram I, Dikshit R, Eser S, Mathers C, Rebelo $\mathrm{M}$, et al. Cancer incidence and mortality worldwide: sources, methods and major patterns in GLOBOCAN 2012. Int J Cancer 2015;136:E359-86. https://doi.org/10.1002/ijc.29210

3. Peng Y, Croce CM. The role of MicroRNAs in human cancer. Signal Transduct Target Ther 2016;1:15004. https://doi.org/10.1038/ sigtrans.2015.4

4. Nagpal N, Kulshreshtha R. miR-191: an emerging player in disease biology. Front Genet 2014;5:99. https://doi.org/10.3389/ fgene.2014.00099

5. Stahlhut Espinosa CE, Slack FJ. The role of microRNAs in cancer. Yale J Biol Med 2006;79:131-40.

6. Sun Y, Wang M, Lin G, Sun S, Li X, Qi J, et al. Serum microRNA-155 as a potential biomarker to track disease in breast cancer. PLoS One 2012;7:e47003. https://doi.org/10.1371/journal. pone. 0047003

7. Zhang X, Wu M, Chong QY, Zhang W, Qian P, Yan H, et al. Amplification of hsa-miR-191/425 locus promotes breast cancer proliferation and metastasis by targeting DICER1. Carcinogenesis 2018;39:1506-16. https://doi.org/10.1093/carcin/bgy102
8. Chen J, Nie S, Hong B, Li C, Xiong T, Shen X, et al. MicroRNA-494 promotes tumor growth by targeting PTEN in non-small cell lung cancer. Int J Clin Exp Pathol 2017;10:4441-50.

9. Qu Y, Zhang H, Sun W, Han Y, Li S, Qu Y, et al. MicroRNA-155 promotes gastric cancer growth and invasion by negatively regulating transforming growth factor- $\beta$ receptor 2 . Cancer Sci 2018;109:618-28. https://doi.org/10.1111/cas.13472

10. Peng WZ, Ma R, Wang F, Yu J, Liu ZB. Role of miR-191/425 cluster in tumorigenesis and diagnosis of gastric cancer. Int J Mol Sci 2014;15:4031-48. https://doi.org/10.3390/ijms15034031

11. He W, Li Y, Chen X, Lu L, Tang B, Wang Z, et al. miR-494 acts as an anti-oncogene in gastric carcinoma by targeting c-myc. J Gastroenterol Hepatol 2014;29:1427-34. https://doi.org/10.1111/ jgh. 12558

12. Shi LJ, Zhang CY, Zhou ZT, Ma JY, Liu Y, Bao ZX, et al. MicroRNA-155 in oral squamous cell carcinoma: overexpression, localization, and prognostic potential. Head Neck 2015;37:970-6. https:// doi.org/10.1002/hed.23700

13. Gissi DB, Morandi L, Gabusi A, Tarsitano A, Marchetti C, Cura $\mathrm{F}$, et al. A noninvasive test for MicroRNA expression in oral squamous cell carcinoma. Int J Mol Sci 2018;19:1789. https://doi. org/10.3390/ijms 19061789

14. Libório-Kimura TN, Jung HM, Chan EK. miR-494 represses HOXA10 expression and inhibits cell proliferation in oral cancer. Oral Oncol 2015;51:151-7. https://doi.org/10.1016/ j.oraloncology.2014.11.019

15. Zahra A, Rubab I, Malik S, Khan A, Khan MJ, Fatmi MQ. Metaanalysis of miRNAs and their involvement as biomarkers in oral cancers. Biomed Res Int 2018;2018:8439820. https://doi. org/10.1155/2018/8439820

16. Troiano G, Mastrangelo F, Caponio VCA, Laino L, Cirillo N, Lo Muzio L. Predictive prognostic value of tissue-based microRNA expression in oral squamous cell carcinoma: a systematic review and meta-analysis. J Dent Res 2018;97:759-66. https://doi. org/10.1177/0022034518762090

17. Patel RS, Jakymiw A, Yao B, Pauley BA, Carcamo WC, Katz J, et al. High resolution of microRNA signatures in human whole saliva. Arch Oral Biol 2011;56:1506-13. https://doi.org/10.1016/ j.archoralbio.2011.05.015

18. Shi X, Su S, Long J, Mei B, Chen Y. MicroRNA-191 targets Ndeacetylase/ $\mathrm{N}$-sulfotransferase 1 and promotes cell growth in human gastric carcinoma cell line MGC803. Acta Biochim Biophys Sin (Shanghai) 2011;43:849-56. https://doi.org/10.1093/abbs/ gmr084

19. Bedewy AML, Elmaghraby SM, Shehata AA, Kandil NS. Prognostic value of miRNA-155 expression in B-cell non-hodgkin lymphoma. Turk J Haematol 2017;34:207-12. https://doi.org/10.4274/ tjh. 2016.0286

20. Iorio MV, Croce CM. microRNA involvement in human cancer. Carcinogenesis 2012;33:1126-33. https://doi.org/10.1093/carcin/ bgs 140

21. Pollutri D, Patrizi C, Marinelli S, Giovannini C, Trombetta E, Giannone FA, et al. The epigenetically regulated miR-494 associates with stem-cell phenotype and induces sorafenib resistance in hepatocellular carcinoma. Cell Death Dis 2018;9:4. https://doi. org/10.1038/s41419-017-0076-6

22. Shih T, Lindley C. Bevacizumab: an angiogenesis inhibitor for the treatment of solid malignancies. Clin Ther 2006;28:1779-802. https://doi.org/10.1016/j.clinthera.2006.11.015

23. Pang W, Su J, Wang Y, Feng H, Dai X, Yuan Y, et al. Pancreatic cancer-secreted miR-155 implicates in the conversion from normal fibroblasts to cancer-associated fibroblasts. Cancer Sci 2015;106:1362-9. https://doi.org/10.1111/cas.12747

24. de Gramont A, Van Cutsem E. Investigating the potential of bevacizumab in other indications: metastatic renal cell, non-small cell lung, pancreatic and breast cancer. Oncology 2005;69 Suppl 3:4656. https://doi.org/10.1159/000088483 
25. Yoshida H, Yoshimura H, Matsuda S, Ryoke T, Kiyoshima T, Kobayashi M, et al. Effects of peritumoral bevacizumab injection against oral squamous cell carcinoma in a nude mouse xenograft model: a preliminary study. Oncol Lett 2018;15:8627-34. https:// doi.org/10.3892/ol.2018.8399

26. Zhao XM, Liu KQ, Zhu G, He F, Duval B, Richer JM, et al. Identifying cancer-related microRNAs based on gene expression data. Bioinformatics 2015;31:1226-34. https://doi.org/10.1093/bioinformatics/btu811

27. Shah MY, Ferrajoli A, Sood AK, Lopez-Berestein G, Calin GA. microRNA therapeutics in cancer - an emerging concept. EBioMedicine 2016;12:34-42. https://doi.org/10.1016/j.ebiom.2016.09.017

28. Hammond SM. MicroRNAs as oncogenes. Curr Opin Genet Dev 2006;16:4-9. https://doi.org/10.1016/j.gde.2005.12.005

29. Hutvágner G, Zamore PD. A microRNA in a multiple-turnover RNAi enzyme complex. Science 2002;297:2056-60. https://doi. org/10.1126/science.1073827

30. Kroh EM, Parkin RK, Mitchell PS, Tewari M. Analysis of circulating microRNA biomarkers in plasma and serum using quantitative reverse transcription-PCR (qRT-PCR). Methods 2010;50:298-301. https://doi.org/10.1016/j.ymeth.2010.01.032

31. Xue X, Liu Y, Wang Y, Meng M, Wang K, Zang X, et al. MiR21 and MiR-155 promote non-small cell lung cancer progression by downregulating SOCS1, SOCS6, and PTEN. Oncotarget 2016;7:84508-19. https://doi.org/10.18632/oncotarget.13022

32. Lu S, Liao QS, Tang L. MiR-155 affects osteosarcoma cell proliferation and invasion through regulating NF- $\mathrm{KB}$ signaling pathway. Eur Rev Med Pharmacol Sci 2018;22:7633-9. https://doi. org/10.26355/eurrev_201811_16380

33. Zare A, Alipoor B, Omrani MD, Zali MR, Malekpour Alamdari N, Ghaedi H. Decreased miR-155-5p, miR-15a, and miR-186 expression in gastric cancer is associated with advanced tumor grade and metastasis. Iran Biomed J 2019;23:338-43. https://doi. org/10.29252/.23.5.338

34. Elyakim E, Sitbon E, Faerman A, Tabak S, Montia E, Belanis L, et al. hsa-miR-191 is a candidate oncogene target for hepatocellular carcinoma therapy. Cancer Res 2010;70:8077-87. https://doi. org/10.1158/0008-5472.CAN-10-1313

35. Liu H, Xu XF, Zhao Y, Tang MC, Zhou YQ, Lu J, et al. MicroRNA-191 promotes pancreatic cancer progression by targeting USP10. Tumour Biol 2014;35:12157-63. https://doi.org/10.1007/ s13277-014-2521-9

36. Zhang XF, Li KK, Gao L, Li SZ, Chen K, Zhang JB, et al. miR-191 promotes tumorigenesis of human colorectal cancer through targeting C/EBP $\beta$. Oncotarget 2015;6:4144-58. https://doi.org/10.18632/ oncotarget.2864

37. Colamaio M, Borbone E, Russo L, Bianco M, Federico A, Califano
D, et al. miR-191 down-regulation plays a role in thyroid follicular tumors through CDK6 targeting. J Clin Endocrinol Metab 2011;96:E1915-24. https://doi.org/10.1210/jc.2011-0408

38. Chen P, Pan X, Zhao L, Jin L, Lin C, Quan J, et al. MicroRNA191-5p exerts a tumor suppressive role in renal cell carcinoma. Exp Ther Med 2018;15:1686-93. https://doi.org/10.3892/etm.2017.5581

39. Macedo T, Silva-Oliveira RJ, Silva VAO, Vidal DO, Evangelista AF, Marques MMC. Overexpression of mir-183 and mir-494 promotes proliferation and migration in human breast cancer cell lines. Oncol Lett 2017;14:1054-60. https://doi.org/10.3892/ol.2017.6265

40. Liu K, Liu S, Zhang W, Jia B, Tan L, Jin Z, et al. miR-494 promotes cell proliferation, migration and invasion, and increased sorafenib resistance in hepatocellular carcinoma by targeting PTEN. Oncol Rep 2015;34:1003-10. https://doi.org/10.3892/ or.2015.4030

41. Zhang Y, Guo L, Li Y, Feng GH, Teng F, Li W, et al. MicroRNA-494 promotes cancer progression and targets adenomatous polyposis coli in colorectal cancer. Mol Cancer 2018;17:1. https:// doi.org/10.1186/s12943-017-0753-1

42. Yang YK, Xi WY, Xi RX, Li JY, Li Q, Gao YE. MicroRNA-494 promotes cervical cancer proliferation through the regulation of PTEN. Oncol Rep 2015;33:2393-401. https://doi.org/10.3892/ or.2015.3821

43. Yuan J, Wang K, Xi M. MiR-494 inhibits epithelial ovarian cancer growth by targeting c-Myc. Med Sci Monit 2016;22:617-24. https://doi.org/10.12659/msm.897288

44. Zhao Z, Xia G, Li N, Su R, Chen X, Zhong L. Autophagy inhibition promotes bevacizumab-induced apoptosis and proliferation inhibition in colorectal cancer cells. J Cancer 2018;9:3407-16. https://doi.org/10.7150/jca.24201

45. Kang YK, Kang WK, Shin DB, Chen J, Xiong J, Wang J, et al. Capecitabine/cisplatin versus 5-fluorouracil/cisplatin as first-line therapy in patients with advanced gastric cancer: a randomised phase III noninferiority trial. Ann Oncol 2009;20:666-73. https:// doi.org/10.1093/annonc/mdn717

How to cite this article: Emami N, Mohamadnia A, Mirzaei M, Bayat M, Mohammadi F, Bahrami N. miR-155, miR-191, and miR-494 as diagnostic biomarkers for oral squamous cell carcinoma and the effects of Avastin on these biomarkers. J Korean Assoc Oral Maxillofac Surg 2020;46:341-347. https://doi.org/10.5125/ jkaoms.2020.46.5.341 